\title{
Pembinaan Penanda Molekul bagi Kultur Tisu Kelapa Sawit Prolifik
}

\author{
(Construction of Molecule Markers for Prolific Oil Palm Tissue Culture)
}

\author{
SiTI KHADIJAH A. KARIM* \& NIK MARZUKI SIDIK
}

\begin{abstract}
ABSTRAK
Penggunaan penanda DNA boleh mengurangkan masalah dalam kultur tisu khususnya apabila diaplikasikan semasa pemilihan pokok untuk kultur tisu. Oleh itu, penyelidikan ini dijalankan bertujuan untuk membina penanda molekul bagi kultur tisu kelapa sawit prolifik dengan menggunakan teknik polimorfisme panjang cebisan teramplifikasi (AFLP). Analisis AFLP dijalankan ke atas 20 klon kelapa sawit yang terbahagi kepada tiga kelas iaitu klon tidak prolifik (10 jenis klon), klon normal (6 jenis klon) dan klon prolifik (4 jenis klon). Kesemua klon yang digunakan adalah daripada titisan sel yang berbeza. Sebanyak 25 kombinasi pencetus telah digunakan dalam analisis AFLP dan 13 daripada mereka memberikan corak amplifikasi polimorfisme. Daripada hasil ini, sebanyak 44 cebisan polimorfik telah dipencilkan dengan 33 cebisan adalah bagi klon tidak prolifik, 1 cebisan bagi normal dan 10 cebisan bagi klon prolifik. Cebisan ini telah diklon ke dalam plasmid, berjujukan dan seterusnya, analisis jujukan dijalankan. Sebanyak 36 cebisan polimorfik telah digunakan bagi kajian seterusnya. Berdasarkan kepada jujukan yang diperoleh, sepasang pencetus yang khusus kepada setiap cebisan telah dijana. Jangkaan julat saiz jalur DNA yang diamplifikasi bagi setiap pencetus adalah antara 70 hingga 500 bp. Pasangan pencetus yang optimum diuji ke atas 20 jenis klon kelapa sawit untuk mengesahkan penanda yang telah dibina. Daripada 36 pasangan pencetus yang dibina, 2 pasang pencetus telah menunjukkan potensi untuk digunakan sebagai penanda kepada kultur tisu kelapa sawit prolifik.
\end{abstract}

Kata kunci: AFLP; kelapa sawit; kultur tisu; penanda DNA

\section{ABSTRACT}

The use of DNA marker could minimize problems in tissue culture especially when applied during the selection of plants for tissue culture. Therefore, the aimed of this research was to develop molecular markers for prolific oil palm tissue culture using amplified fragment length polymorphism (AFLP) technique. AFLP analysis was carried out upon 20 oil palm clones that have divided into three classes which are non-prolific clone (10 types of clone), normal clone (6 types of clone) and prolific clone (4 types of clone). All of the clones used were from different cell line. There were 25 primer combinations used in the AFLP analysis and 13 out of them have produced significant polymorphic amplification patterns. From these results, 44 polymorphic DNA fragments were isolated where 33 fragments for non-prolific clone, one fragment for normal clone and 10 fragments for prolific clone. These fragments were cloned into plasmid, sequenced and then sequence analysis was done. There were 36 polymorphic fragments have undergone the subsequent experiments. A pair of specific primers for each fragment was designed based on their sequences. The expected size of amplified DNA bands for each primer pair was between $70 \mathrm{bp}$ to $500 \mathrm{bp}$. The optimized primer pairs were tested to the 20 types of oil palm clones in order to confirm the markers developed. From the 36 designated primers combinations, 2 pairs of the primers showed the potential to be used as marker for prolific oil palm tissue culture.

Keywords: AFLP; DNA marker; palm oil; tissue culture

\section{PENGENALAN}

Kelapa sawit (Elaeis guineensis Jacq.) adalah tumbuhan yang mempunyai kepentingan ekonomi kerana ia adalah sumber minyak masak kedua terbesar dunia selepas kacang soya. Kelapa sawit banyak ditanam di kawasan tropika Asia, Amerika Latin dan Afrika. Dianggarkan pada tahun 2020, 26\% sumber minyak dan lemak dunia akan disumbangkan oleh hasil sawit dan dengan itu minyak sawit akan mendominasi 50\% daripada dagangan minyak dan lemak pada peringkat global (Rajanaidu \& Jalani 1995; Woittiez et al. 2017). Jumlah pengeluaran purata sebuah negara pengeluar minyak sawit adalah dianggarkan antara
10-11 tan minyak sehektar dalam setahun (Breure 2003; Hoffmann et al. 2017). Peningkatan daripada segi biak baka dan hasil yang diperoleh daripada sawit giat dijalankan untuk menghasilkan kultivar yang mempunyai ciri-ciri yang dikehendaki. Contohnya kerintangan terhadap penyakit, kadar pertumbuhan yang tinggi dan hasil minyak sawit yang berkualiti dengan jumlah yang banyak. Pelbagai kaedah dan kajian telah dijalankan untuk meningkatkan kecekapan penghasilan minyak sawit disebabkan keperluan minyak sawit yang semakin meningkat seiring dengan pertambahan populasi dunia. Secara konvensional, pokok sawit biasanya ditanam menggunakan teknik 
pembiakan melalui biji benih. Pembiakan melalui biji benih adalah pembiakan tanaman melalui persenyawaan tumbuhan. Meskipun terdapat beberapa kemajuan yang menghasilkan biak baka yang baik melalui pemilihan biji benih bermutu, namun proses ini mengambil masa yang lama untuk memperoleh hasilnya (Jouannic et al. 2005; Tan et al. 2016). Selain itu, terdapat banyak masalah yang dihadapi oleh pembiak baka dalam mendapatkan hasil sawit bermutu. Antara masalah yang paling biasa ditemui dalam penanaman sawit adalah seperti kandungan minyak yang rendah dan kadar pembiakan yang perlahan. Ini menyebabkan kadar penghasilan dan kualiti minyak sawit menjadi tidak seragam (Murphy 2017). Masalah lain yang biasanya dihadapi dalam penanaman melalui biji benih ini adalah terdapatnya variasi genetik antara satu pokok dengan pokok yang lain. Oleh kerana setiap kitar pemilihan tanaman memerlukan masa kira-kira 10 tahun, ini membuatkan perkembangan genetik menjadi sangat perlahan serta penggunaan tenaga kerja dan masa yang lama. Ia adalah akibat daripada proses pencirian biologi kelapa sawit (kitar hidup yang panjang dan tiada pembiakan vegetatif semula jadi) dan juga variasi genetik yang tinggi antara hibrid.

Teknik kultur tisu membenarkan penambahan bilangan suatu tumbuhan yang mempunyai ciri-ciri yang dikehendaki dengan banyak dalam jangka masa yang singkat. Walaupun teknik kultur tisu berupaya menghasilkan planlet yang bersifat serupa dengan induk, sebahagian daripada klon gagal untuk memberikan hasil yang dijangkakan akibat perubahan dalam corak pengekspresan gen. Ini adalah kerana proses embriogenesis somatik menyebabkan berlakunya perubahan biokimia dan morfologi sepanjang perkembangan tisu kalus (Karam et al. 2017; Sharp et al. 1980). Dalam teknik kultur tisu, tidak semua kalus yang dikulturkan akan menghasilkan pucuk disebabkan regenerasi tumbuhan tidak berlaku semasa proses mikroperambatan dijalankan. Hipotesis pertama mencadangkan bahawa terdapat variasi genetik dalam populasi sel (Makowska et al. 2017; Orton 1980). Hipotesis kedua mencadangkan bahawa terdapat sejenis bahan semula jadi yang merangsang proses morfogenesis pada eksplan yang baru dipencilkan yang akan merosot dalam keadaan in vitro (Ikeuchi et al. 2016; Reinert \& Backs 1968). Ini bermakna terdapat peningkatan dalam bahan perencat morfogenesis yang berkadar langsung dengan masa. Hipotesis ketiga pula mencadangkan terdapat perubahan genetik ke atas sel-sel yang dikulturkan dan mekanisme regulasi yang berperanan untuk mengekspreskan ciri morfogenesis telah dinyahaktifkan atau hilang ketika pensubkulturan berterusan dijalankan (Hossain et al. 2016; Rice et al. 1979).

Penanda molekul telah memainkan peranan yang besar dalam pencirian genetik dan peningkatan bagi spesies tanaman. Ia juga telah menyumbang dan meningkatkan keupayaan saintis untuk mengkaji kepelbagaian biologi, membina semula perhubungan filogenetik yang lebih tepat dan memahami strukturnya, evolusi dan interaksi tumbuhan dan populasi mikrob.
Sistem penanda molekul telah mendedahkan variasi yang terdapat dalam jujukan DNA genom.

Kelapa sawit adalah spesies yang mempunyai kepentingan ekonomi kerana ia merupakan sumber minyak masak kedua terbesar di dunia selepas kacang soya. Kejayaan mikropropagasi terhadap kelapa sawit telah diterima dengan tarikan yang besar daripada industri kelapa sawit. Ia memberikan cara untuk pembiakbakaan material elit terpilih dengan pembenihan hibrid DxP yang merupakan persilangan antara Dura dan Pisifera diharap dapat dikomersialkan (Low et al. 2006). Tanaman hasil persilangan tersebut disebut Tenera. Pada pertengahan 1980-an, perkembangan tidak normal pada bunga untuk klon-klon kelapa sawit telah dilaporkan oleh United Plantations Berhad (Malaysia), Malaysia. Seterusnya, beberapa organisasi lain juga melaporkan ketidaknormalan antara bahan mereka yang dibiakbakakan melalui kultur tisu.

Masalah lain yang menghalang proses pengkomersialan mikropropagasi kelapa sawit adalah ketidakberkesanan proses kultur tisu kelapa sawit. Kadar pembentukan kalus bagi eksplan kelapa sawit masih sangat rendah, kira-kira 19\% (Corley \& Tinker 2003; Roberts et al. 2017), sementara kadar embriogenesis daripada kultur kalus yang aktif hanya sebanyak enam peratus. Sebab-sebab inilah yang memberikan motivasi kepada industri dalam meningkatkan usaha untuk memahami dan memperbaiki keberkesanan kultur tisu kelapa sawit dan pada masa yang sama mengurangkan atau mengawal fenomena ketidaknormalan.

Selain itu, mikroperambatan sejumlah besar klon-klon kelapa sawit yang dihasilkan melalui teknik kultur tisu juga mengalami masalah daripada segi tahap regenerasi yang rendah dan tidak semua kalus akan melalui peringkat embrio somatik dan berkembang menjadi plantlet yang normal. Oleh itu, kos mikroperambatan dan penyelenggaraan bilangan eksplan dan kalus yang banyak bagi jangka masa yang panjang memakan belanja yang tinggi dan menjadi masalah utama yang perlu diselesaikan.

Hampir tiga dekad setelah kejayaan pembiakbakaan kelapa sawit melalui kultur tisu, terdapat prosedur kultur tisu yang boleh dipercayai dan telah membantu meningkatkan keberkesanan kultur tisu dan mengurangkan ketidaknormalan. Walau bagaimanapun, syarikat perladangan yang besar masih ragu-ragu tentang pembiakbakaan kultur tisu berskala besar disebabkan kejadian ketidaknormalan dalam kultur tisu.

Peningkatan populariti biologi molekul dan terciptanya teknologi penanda molekul dalam era 1980an dan 1990-an telah memberikan harapan baru kepada industri. Boleh dikatakan bahawa ilmu baru sains ini berupaya menyelesaikan masalah dalam keberkesanan kultur tisu dan ketidaknormalan pada peringkat molekul. Penanda-penanda boleh dibina untuk mengesan pembentukan kalus, embriogenesis dan ketidaknormalan, menjadikan pembiakbakaan berskala besar boleh dilakukan. 


\section{BAHAN DAN KAEDAH}

SUMBER SAMPEL

Sumber klon kelapa sawit elit E. guineensis Jacq. diperoleh daripada Encik Muhammad Rashdan Muad, Sime Darby Sdn Bhd., Malaysia. Sebanyak 20 klon kelapa sawit yang digunakan dalam kajian ini dibahagikan kepada tiga kumpulan iaitu klon tidak prolifik, normal dan prolifik. Semua DNA genom klon-klon ini dibekalkan oleh Sime Darby Sdn. Bhd.

\section{ANALISIS AFLP}

Pencernaan berganda dilakukan berdasarkan protokol yang telah dinyatakan dalam manual AFLP ${ }^{\circledR}$ Analysis System I. Tiub bagi sampel adalah merujuk kepada salah satu daripada 20 DNA genom klon kelapa sawit yang dikaji (contohnya, klon pertama pokok tidak prolifik). Cara kerja yang diterangkan ini adalah untuk satu jenis DNA genom sahaja. Oleh kerana terdapat 20 sampel DNA yang dikaji, maka tindak balas ini diulang ke atas 20 sampel secara berasingan. $2.5 \mu \mathrm{L}$ DNA tomato kawalan (kepekatan awal $100 \mathrm{ng} / \mu \mathrm{L}$ ) dimasukkan ke dalam tiub kawalan sahaja. $5 \mu \mathrm{L}$ sampel DNA kelapa sawit (250 ng) dimasukkan ke dalam tiub sampel sahaja. Seterusnya, $2 \mu \mathrm{L}$ campuran sedia-guna enzim pembatasan EcoRI dan MseI (kepekatan awal 0.2 mM) dimasukkan ke dalam kedua-dua tiub iaitu tiub kawalan dan tiub sampel supaya kedua-dua DNA sampel dan tomato dapat dicernakan. Akhir sekali, air suling ditambahkan supaya isi padu akhir kedua-dua tiub menjadi $25 \mu \mathrm{L}$. Kedua-dua tiub kemudiannya dieram dalam kukusan air selama 2 jam pada suhu $37^{\circ} \mathrm{C}$. Setelah itu campuran dieramkan selama 15 min pada $70^{\circ} \mathrm{C}$ untuk menyahaktifkan enzim pembatasan. Sebanyak $250 \mathrm{ng} / \mu \mathrm{L}$ DNA adalah mencukupi untuk tindak balas. Analisis AFLP seterusnya dilakukan menuruti langkah-langkah di dalam manual oleh pembekal.

\section{PENENTUAN KEHADIRAN DNA SELITAN MELALUI PCR}

Analisis PCR dijalankan ke atas plasmid yang telah dipencilkan daripada hos E. coli. Ini bertujuan untuk memastikan sama ada plasmid yang dipencilkan membawa DNA selitan yang dikehendaki. Campuran tindak balas PCR mengandungi templat DNA 0.5 $\mu$ L plasmid DNA (kepekatan awal $60 \mathrm{ng}$ ), $0.5 \mu \mathrm{L}$ pencetus E1 (kepekatan awal $27.8 \mathrm{ng} /$ $\mu \mathrm{L}), 4.5 \mu \mathrm{L}$ pencetus M1 (kepekatan awal $6.7 \mathrm{ng} / \mu \mathrm{L}), 2$ $\mu \mathrm{L}$ penimbal tindak balas berkepekatan $10 \mathrm{kali}, 0.5 \mu \mathrm{L}$ DNA polimerase Taq (kepekatan awal 5 unit/ $\mu \mathrm{L}$ ) dan 12 $\mu \mathrm{L}$ air suling. Hasil PCR tersebut kemudiannya dilakukan elektroforesis gel agarosa. Plasmid yang menunjukkan jalur DNA dengan saiz yang dikehendaki sahaja yang dipilih untuk pencernaan plasmid.

\section{PENCERNAAN PLASMID DENGAN ENZIM PEMBATASAN}

Pencernaan ganda dua plasmid dengan enzim pembatasan EcoRI daripada Amersham Biosciences (UK) dijalankan bagi menentukan kehadiran DNA selitan iaitu DNA polimorfik. Campuran tindak balas proses pencernaan plasmid mengandungi tiga $\mu \mathrm{L}$ plasmid, $1 \mu \mathrm{L}$ enzim pembatasan EcoRI. $2 \mu \mathrm{L}$ penimbal $10 \times \mathrm{H}$ dan $14 \mu \mathrm{L}$ air suling ditambahkan ke dalam tiub. Jumlah isi padu yang disediakan adalah $20 \mu \mathrm{L}$. Campuran dieramkan pada suhu $37^{\circ} \mathrm{C}$ selama dua jam. Hasil pencernaan dianalisis dengan menjalankan elektroforesis gel agarosa $1.0 \%$ pada $100 \mathrm{~V}$ selama $55 \mathrm{~min}$.

\section{PENJUJUKAN PLASMID}

Plasmid menjalani penjujukan dengan menggunakan pencetus universal SP6 dan T7. Penjujukan dilakukan oleh Repfon Glamor Sdn. Bhd. dengan menggunakan perisian BLAST melalui NCBI di http://www.ncbi.nlm.gov/, jujukan DNA disejajarkan.

\section{PEMBINAAN PENCETUS}

Berdasarkan jujukan DNA yang telah disejajarkan, pasangan pencetus ke hadapan dan pencetus ke belakang dibina dengan menggunakan perisian 'Primer Primere 5.0'. Pasangan pencetus khusus dibina untuk setiap 36 cebisan DNA polimorfik yang telah diklonkan. Proses sintesis pencetus dijalankan oleh Repfon Glamor Sdn. Bhd.

\section{PENGUJIAN PENANDA KE ATAS DNA GENOM}

Analisis PCR dijalankan bagi setiap 36 pasang pencetus spesifik ke atas 20 DNA genom klon kelapa sawit (sebagai templat) sama seperti yang digunakan semasa analisis AFLP sebelum ini. Terlebih dahulu, templat DNA (DNA genom 20 klon kelapa sawit) dilakukan elektroforesis gel agarosa untuk memastikan keseragaman jumlah DNA setiap klon yang digunakan. Campuran tindak balas PCR mengandungi $1 \mu \mathrm{g}$ templat DNA, $1 \mu \mathrm{L}$ pencetus ke hadapan (kepekatan awal $20 \mu \mathrm{M}$ ) dan $1 \mu \mathrm{L}$ pencetus ke belakang (kepekatan awal $20 \mu \mathrm{M}), 5 \mu \mathrm{L}$ penimbal berkepekatan $10 \mathrm{kali}, 1 \mu \mathrm{L}$ dNTP (kepekatan awal 0.2 mM), 7.5 $\mu \mathrm{L}$ magnesium klorida (kepekatan awal $1.5 \mathrm{mM}$ ), $0.5 \mu \mathrm{L}$ DNA polimerase Taq (5 unit $/ \mu \mathrm{L}$ ) dan $33 \mu \mathrm{L}$ air suling yang steril untuk menjadikan isi padu akhir $50 \mu \mathrm{L}$. Setiap pasangan pencetus diuji dengan menggunakan profil PCR yang telah dioptimum.

\section{KePUTUSAN DAN PERBINCANGAN}

Tiga jenis klon kelapa sawit yang berbeza digunakan dalam kajian ini iaitu klon tidak prolifik, klon normal dan klon prolifik. Klon tidak prolifik diperoleh daripada kalus kelapa sawit yang mempunyai kadar regenerasi yang rendah untuk berkembang menjadi planlet. Klon normal adalah kalus kelapa sawit yang mempunyai kadar regenerasi yang sederhana untuk membentuk planlet. Klon prolifik pula adalah kalus kelapa sawit yang mempunyai kadar regenerasi yang tinggi untuk membentuk planlet. Analisis AFLP menggunakan dua jenis pencetus iaitu pencetus yang berpelengkap dengan hujung melekit EcoRI berserta tiga nukleotida tambahan (E1) dan pencetus yang 
berpelengkap dengan hujung melekit MseI berserta tiga nukleotida tambahan (M1). Kombinasi 8 jenis pencetus E1 dengan 8 pencetus M1 boleh menghasilkan 64 jenis kombinasi pencetus yang berbeza. Kombinasi 25 pencetus E1 (pernomboran 1 hingga 8 digunakan bagi mewakili pencetus E1) dan M1 (abjad A hingga $\mathrm{H}$ digunakan bagi mewakili pencetus M1) yang digunakan semasa analisis AFLP bagi mengesan kehadiran polimorfisme DNA antara klon adalah $2 \mathrm{~F}, 2 \mathrm{G}, 2 \mathrm{C}, 3 \mathrm{D}, 5 \mathrm{H}, 5 \mathrm{E}, 4 \mathrm{~B}, 4 \mathrm{C}, 2 \mathrm{H}, 7 \mathrm{C}$, 2B, 3C, 4H, 2D, 2E, 3A, 3G, 3H, 4D, 4E, 4F, 4G, 1D, $5 \mathrm{~A}$, dan 5B. Walau bagaimanapun, hanya 13 kombinasi pencetus telah berjaya menghasilkan jalur-jalur DNA (corak amplifikasi) yang signifikan untuk menunjukkan perbezaan genetik antara klon-klon. Sebanyak 42 jalur DNA polimorfik dikesan daripada 13 kombinasi pencetus tersebut dengan 11 daripadanya adalah cebisan DNA polimorfik klon prolifik, 1 cebisan DNA polimorfik bagi klon normal dan 30 cebisan DNA polimorfik bagi klon tidak prolifik. Rajah 1 menunjukkan 42 jalur DNA polimorfik yang telah dikenal pasti melalui analisis AFLP.

Analisis AFLP menunjukkan polimorfisme DNA dilihat sebagai jalur yang hadir atau tiada jalur yang hadir pada setiap klon sebagaimana yang dapat dilihat pada DNA polimorfik 2F1 dan 4B12. Kedua-dua jalur DNA ini adalah calon bagi penanda tidak prolifik. Jalur DNA polimorfik ini menunjukkan kehadiran jalur DNA

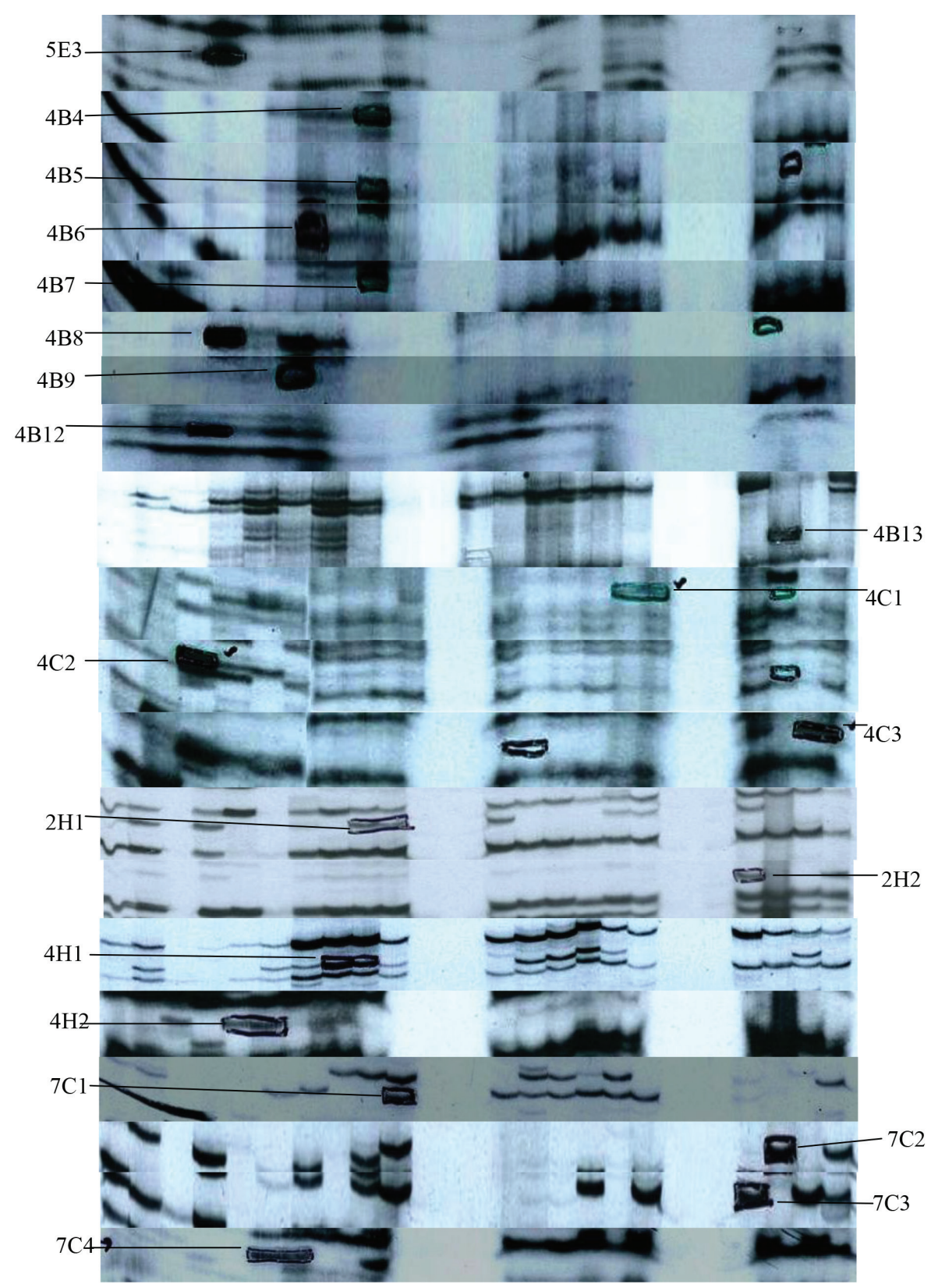

RAJAH 1. Rajah menunjukkan keratan filem autoradiograf bagi 42 cebisan DNA polimorfik yang dikenal pasti. Analisis AFLP dijalankan dengan menggunakan 20 DNA genom kelapa sawit yang diuji dengan 13 kombinasi pencetus yang berbeza. Kehadiran cebisan DNA polimorfik adalah seperti yang ditunjukkan. Telaga 1-10, klon tidak prolifik; 11-16, klon normal; 17-20 klon prolifik 
semua klon tidak prolifik dan normal tetapi tiada jalur hadir pada semua klon prolifik. Variasi ini berlaku disebabkan kekurangan atau kelebihan dalam turutan bes pada cebisan DNA, menyebabkan jujukan pencetus yang digunakan tidak dapat mengikat pada templat, maka tiada jalur DNA dihasilkan (Costa et al. 2016; Meudt \& Clarke 2007). Perbezaan pada susunan bes ini dapat dilihat di antara klon telah menjadi konsep dalam pembinaan penanda DNA. Klon yang menghasilkan jalur DNA pada gel poliakrilamida mempunyai turutan atau cebisan DNA yang tidak terdapat pada klon yang tidak menghasilkan jalur DNA. Cebisan DNA ini berkemungkinan mengandungi gen atau kod protein yang berfungsi dalam mengawal atur kadar pertumbuhan klon tersebut. Analisis jujukan akan dibincangkan kemudian. Walaupun tumpuan diberikan pada pembinaan penanda prolifik, calon bagi penanda tidak prolifik juga diambil kira. Penemuan penanda tidak prolifik juga boleh membantu dalam pengenalpastian klon prolifik.

\section{PENGKLONAN CEBISAN DNA POLIMORFIK}

Jalur-jalur DNA yang telah dikenal pasti sebagai penanda dipencilkan daripada gel yang telah dikeringkan di atas kertas Whatmann terlebih dahulu. Jalur DNA yang telah dipencilkan digunakan sebagai templat dalam amplifikasi semula dengan menggunakan pasangan pencetus yang sama yang memberikan polimorfisme DNA. Elektroforesis gel agarosa dijalankan bagi melihat jalur-jalur DNA yang terhasil. Tujuan langkah amplifikasi semula ini adalah untuk mendapatkan DNA templat bagi tujuan pencirian jalur DNA polimorfik. Selain itu, saiz bagi jalur DNA polimorfik yang dipencilkan dapat diketahui daripada proses amplifikasi semula PCR ini. Julat saiz jalur DNA yang diperoleh adalah antara 100 hingga 1000 pb. Sebanyak 42 jalur DNA polimorfik telah berjaya menjalani proses amplifikasi semula PCR seperti yang ditunjukkan dalam Rajah 2.
Rajah 3 menunjukkan gel elektroforesis agarosa bagi pencernaan oleh enzim pembatasan EcoRI yang dijalankan ke atas semua 36 plasmid rekombinan. Berdasarkan keputusan yang diperoleh, semua pencernaan dapat menghasilkan dua jalur iaitu jalur bagi vektor pengklonan pDrive (Qiagen, USA) yang bersaiz $3.85 \mathrm{~kb}$ dan juga jalur DNA selitan yang mempunyai saiz yang berbeza seperti yang ditunjukkan dalam rajah. Vektor pengklonan pDrive mempunyai tapak pembatasan EcoRI di kedua-dua hujung promoter T7 dan SP6 yang berada di tapak pengklonan berbilangnya. Oleh itu, plasmid rekombinan dicernakan dengan menggunakan satu jenis enzim pembatasan sahaja iaitu EcoRI untuk mendapatkan dua jalur DNA berasingan iaitu vektor pengklonan dan DNA selitan. Berdasarkan keputusan yang diperoleh, setiap plasmid rekombinan membawa DNA selitan yang betul berdasarkan saiz jalur yang dihasilkan. Ini membuktikan kejayaan dalam proses pengklonan DNA polimorfik yang dijalankan.

Setiap plasmid rekombinan yang telah dicerna menghasilkan dua jalur DNA iaitu jalur bagi vektor pengklonan yang bersaiz $3.85 \mathrm{~kb}$ dan jalur DNA selitan. DNA selitan adalah DNA polimorfik yang diperoleh semasa analisis AFLP.

\section{PENJUJUKAN DAN ANALISIS JUJUKAN}

Kesemua 36 sampel plasmid mengandungi DNA polimorfik sahaja. DNA selitan dijujuk dengan menggunakan pencetus universal SP6 dan T7. Hasil penjujukan disejajar menggunakan program 'BLAST' dan pembinaan pasangan pencetus dilakukan menggunakan perisian 'Primer Premier 5.0'. Analisis ini dijalankan untuk melihat kepadanan jujukan nukleotida dengan kultivar lain. Walau bagaimanapun, analisis jujukan ini tidak mempengaruhi atau menentukan analisis seterusnya. Tujuan utama penjujukan sesuatu struktur DNA seperti
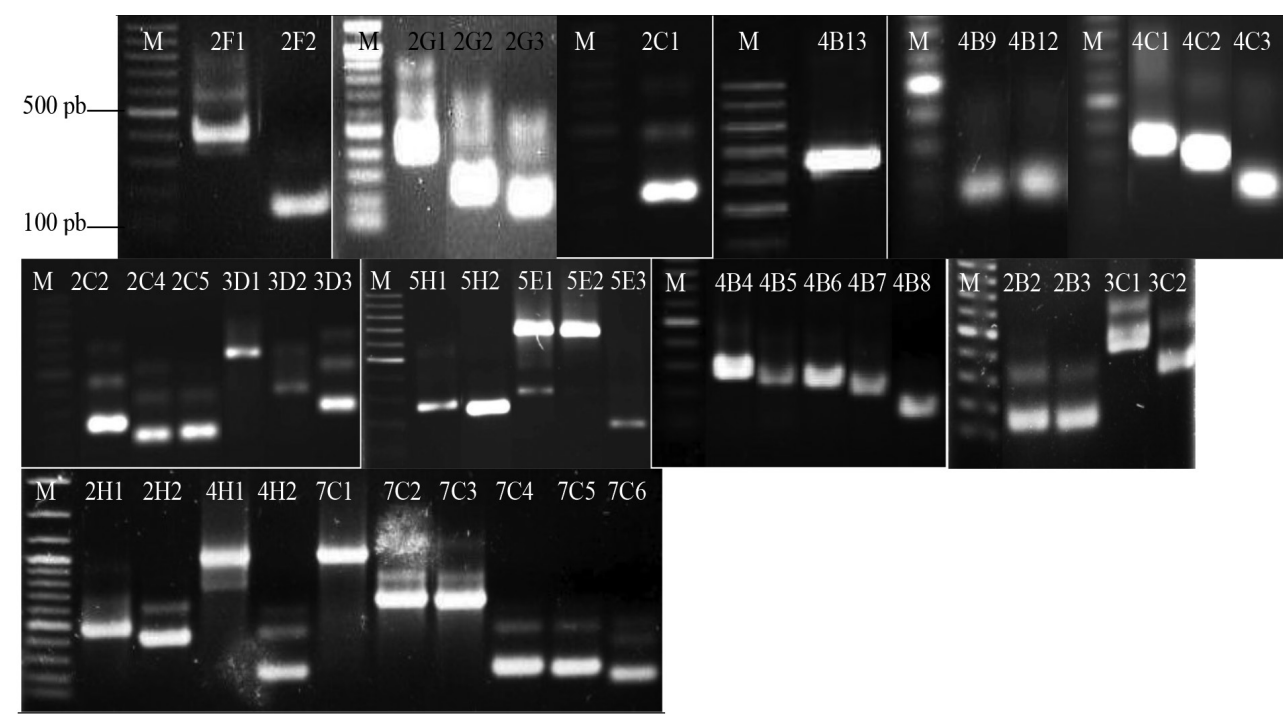

RAJAH 2. Gel elektroforesis agarosa 1.0 menunjukkan hasil amplifikasi PCR semula bagi 42 cebisan DNA polimorfik yang telah ditulenkan daripada keputusan pada Rajah 4.1. M adalah penanda tetangga 100 pb (Vivantis) 


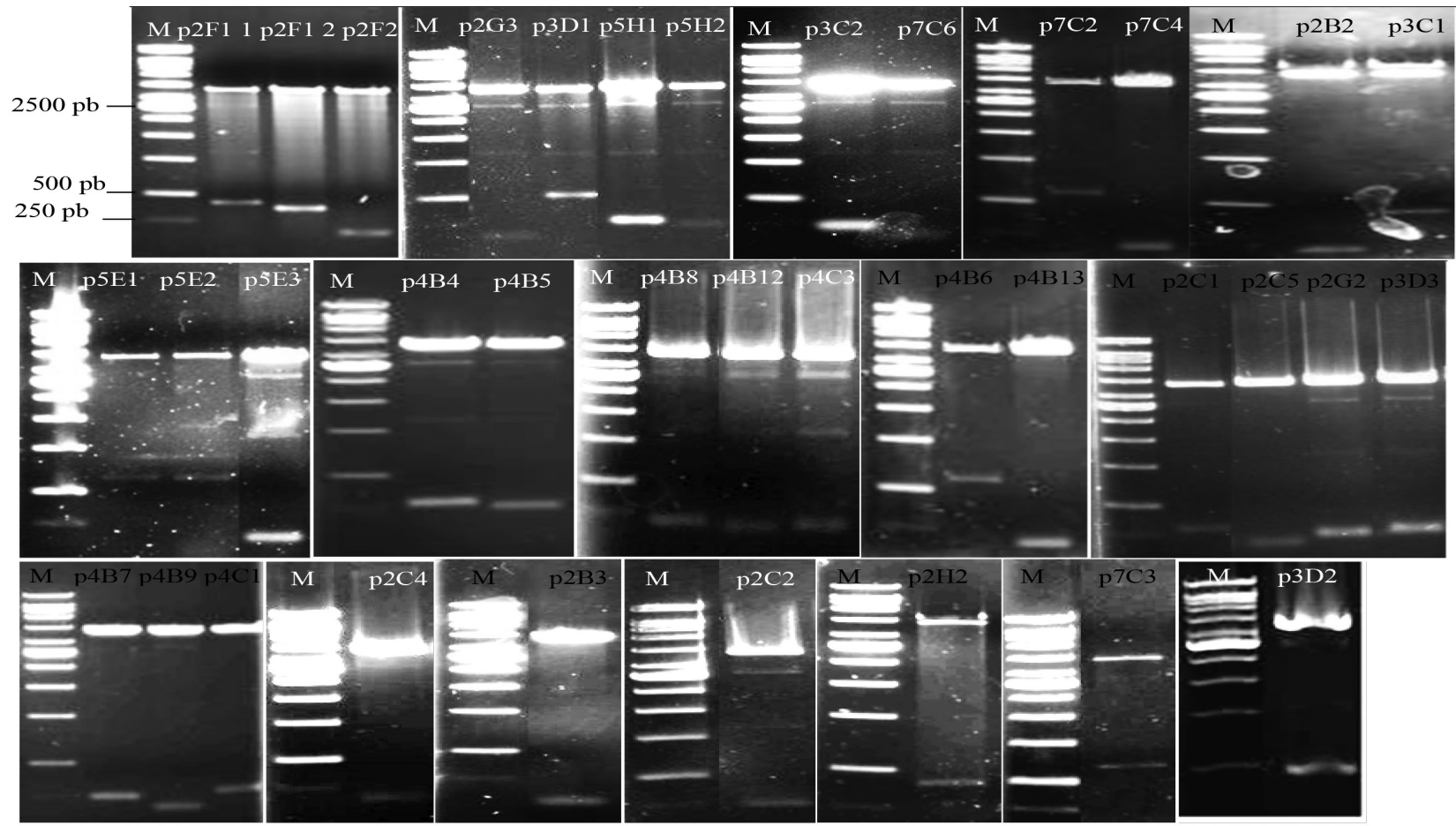

RAJAH 3. Rajah menunjukkan gel elektrofresis agarosa $1.0 \%$ pencernaan ganda dua bagi 36 plasmid. Hasil gel elektroforesis menunjukkan kehadiran dua jalur DNA. Jalur DNA pertama menunjukkan vektor pengklonan bersaiz $3.85 \mathrm{~kb}$ manakala jalur kedua adalah jalur DNA selitan iaitu DNA polimorfik calon penanda dengan saiz berbeza-beza seperti yang telah dilabel. Identiti sampel ditulis pada bahagian atas telaga. M-penanda DNA $1 \mathrm{~kb}$

JADUAL 1. Hasil analisis jujukan DNA selitan menggunakan BLAST (http://www.ncbi.nlm.nih.gov/). Perbandingan jujukan dilakukan terhadap jujukan dalam pengkalan data gen bank

\begin{tabular}{|c|c|c|c|c|c|}
\hline Bil. & $\begin{array}{l}\text { Identiti } \\
\text { klon }\end{array}$ & $\begin{array}{c}\text { Padanan dengan jujukan } \\
\text { pengkalan data }\end{array}$ & No. Pengenalan & Organisma & $\%$ identiti \\
\hline 1. & $2 \mathrm{~F} 11$ & Penanda molekul AFLP & EU293614.1 & Bacillus circulans & $100 \%$ \\
\hline 2. & $2 \mathrm{~F} 12$ & Jujukan mikrosatelit & EF081015.1 & Hieracium pilosella & $86 \%$ \\
\hline 3. & $2 \mathrm{~F} 2$ & Cebisan cDNA-AFLP & AM232566.1 & Catharanthus roseus & $100 \%$ \\
\hline 4. & $2 \mathrm{G} 2$ & Jujukan genomik & AC023628.3 & Arabidopsis thaliana & $90 \%$ \\
\hline 5. & $2 \mathrm{G} 3$ & Penanda molekul AFLP & DQ990819.1 & Borojoa patinoi & $100 \%$ \\
\hline 6. & $2 \mathrm{C} 1$ & Jujukan mikrosatelit & EF081015.1 & Hieracium pilosella & $100 \%$ \\
\hline 7. & $2 \mathrm{C} 2$ & DNA mikrosatelit & AJ865182.1 & Cocos nucifera & $76 \%$ \\
\hline 8. & $2 \mathrm{C} 4$ & Jujukan penanda & AY520580.1 & Rumex acetosa & $100 \%$ \\
\hline 9 & $2 \mathrm{C} 5$ & Jujukan mikrpsatelit & EU416774.1 & Trifolium repens & $96 \%$ \\
\hline 10. & 3D1 & Jujukan mikrosatelit & EU599442.1 & Verasper variegatus & $100 \%$ \\
\hline 11. & 3D2 & Protein hipotetikal & XM 725549.1 & Plasmodium yoelii & $85 \%$ \\
\hline 12. & 3D3 & Jujukan mikrosatelit & AY389512.1 & Fenneropenaeus chinensis & $93 \%$ \\
\hline 13. & $5 \mathrm{H} 1$ & Cebisan cDNA & ВТ039325.1 & Zea mays & $73 \%$ \\
\hline 14. & $5 \mathrm{H} 2$ & DNA kloroplas & AB286870.1 & Olea europaea & $100 \%$ \\
\hline 15. & $5 \mathrm{E} 1$ & Jujukan penanda & AY520575.1 & Rumex acetosa & $93 \%$ \\
\hline 16. & $5 \mathrm{E} 2$ & Jujukan genomik & AY585884.1 & Triticum aestivum & $94 \%$ \\
\hline 17. & $5 \mathrm{E} 3$ & Cebisan cDNA-AFLP & EF415843.1 & Sesbania rostrata & $96 \%$ \\
\hline 18. & 4B4 & Jujukan mikrosatelit & DQ412956.1 & Macadamia integrifolia & $100 \%$ \\
\hline 19 & $4 \mathrm{~B} 5$ & Penanda molekul AFLP & DQ990819.1 & Borojoa patinoi & $100 \%$ \\
\hline 20. & 4B6 & $\begin{array}{l}\text { Gen putatif selulosa sintase gen } \\
\text { katalitik subunit (CesA2) }\end{array}$ & AF254895.1 & Gossypium hirsutum & $79 \%$ \\
\hline 21. & 4B7 & Jujukan mikrosatelit & AY790332.1 & Anser cygnoides & $100 \%$ \\
\hline
\end{tabular}


Sambungan JADUAL 1.

\begin{tabular}{|c|c|c|c|c|c|}
\hline Bil. & $\begin{array}{l}\text { Identiti } \\
\text { klon }\end{array}$ & $\begin{array}{c}\text { Padanan dengan jujukan } \\
\text { pengkalan data }\end{array}$ & No. Pengenalan & Organisma & $\%$ identiti \\
\hline 22. & $4 \mathrm{~B} 8$ & Jujukan penanda DNA & AY190531.1 & Angelica gigas & $100 \%$ \\
\hline 23. & 4B9 & Penanda molekul AFLP & DQ990819.1 & Borojoa patinoi & $98 \%$ \\
\hline 24. & 4B 12 & Jujukan genom & AM480977.1 & Vitis vinifera & $81 \%$ \\
\hline 25. & 4B 13 & Jujukan genom & СР000094.1 & Pseudomonas fluorescens & $74 \%$ \\
\hline 26. & $4 \mathrm{C} 1$ & Jujukan genom & СР000820.1 & Frankia $\mathrm{sp}$ & $96 \%$ \\
\hline 27. & $4 \mathrm{C} 3$ & Jujukan mikrosatelit & DQ002015.1 & Eurycorymbus cavaleriei & $86 \%$ \\
\hline 28. & $2 \mathrm{H} 2$ & $\begin{array}{l}\text { DNA kloroplas, pemencilan: } \\
\text { AFLP-333OilT }\end{array}$ & AB286870.1 & Olea europaea & $89 \%$ \\
\hline 29. & $7 \mathrm{C} 2$ & Jujukan mikrosatelit & AB292170.1 & Durio zibethinus & $96 \%$ \\
\hline 30. & $7 \mathrm{C} 3$ & Jujukan mikrosatelit & EU599442.1 & Verasper variegatus & $100 \%$ \\
\hline 31. & $7 \mathrm{C} 4$ & Jujukan mikrosatelit & DQ002019.1 & Eurycorymbus cavaleriei & $100 \%$ \\
\hline 32. & $7 \mathrm{C} 6$ & Jujukan mikrosatelit & DQ002020.1 & Eurycorymbus cavaleriei & $100 \%$ \\
\hline 33. & $2 \mathrm{~B} 2$ & Cebisan AFLP & EU827242.1 & Fusarium virguliforme & $100 \%$ \\
\hline 34. & $2 \mathrm{~B} 3$ & Cebisan AFLP & AY522659.1 & Rumex acetosa & $100 \%$ \\
\hline 35. & $3 \mathrm{C} 1$ & Cebisan AFLP & AY522660.1 & Rumex acetosa & $10 \%$ \\
\hline 36. & $3 \mathrm{C} 2$ & DNA mitokondria & BA000042.1 & Nicotiana tabacum & $97 \%$ \\
\hline
\end{tabular}

plasmid rekombinan, gen atau DNA genom adalah bagi menentukan jujukan bes yang terdapat pada DNA tersebut. Berdasarkan Jadual 1, kebanyakan klon menunjukkan padanan dengan jujukan penanda atau mikrosatelit daripada pelbagai organisma dalam pengkalan data gen bank.

\section{KESIMPULAN}

Dengan menggunakan teknik pencapjarian AFLP, sebanyak 25 kombinasi pencetus E1 dan M1 telah diskrin untuk mengenal pasti DNA polimorfik daripada 3 jenis klon kelapa sawit yang dipilih dan dikelaskan berdasarkan tahap regenerasinya iaitu klon tidak prolifik, klon normal dan klon prolifik. Dalam kajian ini, sebanyak 20 klon kelapa sawit digunakan iaitu 10 bagi klon tidak prolifik, 6 bagi klon normal dan 4 bagi klon prolifik. Daripada analisis AFLP, 42 calon penanda telah dikenal pasti dengan 11 daripadanya adalah calon penanda prolifik, satu calon penanda normal manakala 30 daripadanya adalah calon penanda tidak prolifik. Kajian ini berjaya memperoleh dua penanda bagi gen prolifik kelapa sawit iaitu dua penanda prolifik $2 \mathrm{H} 2$ dan $7 \mathrm{C} 2$.

\section{PENGHARGAAN}

Penulis berterima kasih kepada Sime Darby Sdn Bhd. dan pengurus projek Muhamad Rashdan Bin Muad atas sumber bahan kajian yang diberikan dan Universiti Kebangsaan Malaysia atas sumbangan tempat kajian, alatan dan bahan kimia.

\section{RUJUKAN}

Breure, K. 2003. The search for yield in oil palm: Basic principles in 'The oil palm management for large and sustainable yields'. Potash Institute of Canada and International Potash Institute. pp. 59-98.
Corley, R.H.V. \& Tinker, P.B. 2003. The Oil Palm. Oxford: Blackwell Science.

Costa, R., Pereira, G., Garrido, I., Tavares-de-Sousa, M.M. \& Espinosa, F. 2016. Comparison of RAPD, ISSR, and AFLP molecular markers to reveal and classify orchardgrass (Dactylis glomerata L.) germplasm variations. PloS One 11(4): e0152972.

Hoffmann, M.P., Donough, C.R., Cook, S.E., Myles, J.F., Lim, C.H., Lim, Y.L. \& Cock, J. 2017. Yield gap analysis in oil palm: Framework development and application in commercial operations in Southeast Asia. Agricultural Systems 151: 12-19.

Hossain, A.B.M.S., Imdadul, H., Mohammed, S.A., Nasir, A.I. \& Kamaludin, R. 2017. Callus cell proliferation and explants regeneration using broccoli shoot tip in vitro culture. Biochemical and antioxidant properties. British Journal of Applied Science \& Technology 13: 1-8.

Ikeuchi, M., Yoichi, O., Akira, I. \& Keiko, S. 2016. Plant regeneration: Cellular origins and molecular mechanisms. Development 143(9): 1442-1451.

Jouannic, S., Argout, X., Lechauve, F., Fizames, C., Borgel, A., Morcillo, F., Aberlenc-Bertossi, F., Duval, Y. \& Tregear, J. 2005. Analysis of expressed sequence tags from oil palm (Elaies guineensis). FEBS Letters 579: 2709-2714.

Karam M.S. Ali, Ali M. Sabbour, Mohamed K. Khalil, AbdelHalim S. Aly \& Amal F.M. Zein El Din. 2017. In vitro morphogenesis of direct organs in date palm (Phoenix dactylifera L.) Siwy cv. International Journal of Advances in Agricultural Science and Technology 4(2): 01-12.

Low, E.T.L., Tan, J.S., Chan, P.L., Boon, S.H., Wong, Y.L., Rozana, R., Ooi, L.C.L., Ma, L.S., Ong-Abdullah, M., Cheah, S.C. \& Rajinder, S.I.N.G.H. 2006. Developments toward the application of DNA chip technology in oil palm tissue culture. Journal of Oil Palm Research 18 (Special Issue): 87-98.

Makowska, K., Marta, K., Sylwia, O., Janusz, Z., Andrzej, C. \& Robert, K. 2017. Arabinogalactan proteins improve plant regeneration in barley (Hordeum vulgare L.) anther culture. Plant Cell, Tissue and Organ Culture (PCTOC) 131(2): 247-257. 
Meudt, H.M. \& Clarke, A.C. 2007. Almost forgotten or latest practice? AFLP applications, analyses and advances. Trends in Plant Sciences 12(3): 106-117.

Murphy, D.J. 2017. Recent scientific developments in genetic technologies: Implications for future regulation of GMOs in developing countries. Genetically Modified Organisms in Developing Countries. p. 13

Orton, T.J. 1980. Chromosome viability in tissue cultures and regenerated plants of Horedum. Theor. Appl. Genet 56: 101-112.

Rajanaidu, N. \& Jalani, B.S. 1995. World-wide performance of DXP planting materials and future prospects. In Proc. 1995 PORIM National Oil Palm Conf.-Tech. pp. 1-29.

Reinert, J. \& Backs, D. 1968. Control of totipotency in plant cells growing in vitro. Nature 220: 1340-1341.

Rice, T.B., Reid, R.K. \& Gordon, P.N. 1979. Morphogenesis in Field Crops. New York: Hughes Publications.

Roberts, J., Siew, E.O., Ahmad, T.H., Zamzuri, I., Samsul, K.R., Wei, C.W., Chin, N.C., Sau, Y.K., Nuraziyan, A. \& Norashikin, S. 2017. Clonal propagation. Dlm. Oil Palm Breeding: Genetics and Genomics. Florida: CRC Press.

Sharp, W.R., Sondhal, M.R., Caldas, L.S. \& Maraffa, S.B. 1980. The physiology of in vitro asexual embryogenesis. Horticult. Rev. 2: 47-54.

Tan, Y.C., Ho, W.Y., Alitheen, N.B., Wong, M.Y. \& Ho, C.L. 2016. Cloning and expression of oil palm (Elaeis guineensis Jacq.) Type 2 ribosome inactivating protein in Escherichia coli. International Journal of Peptide Research and Therapeutics 22(1): 37-44.
Woittiez, L.S., Mark, T.W., Maja, S., Meine, N. \& Ken, E.G. 2017. Yield gaps in oil palm: A quantitative review of contributing factors. European Journal of Agronomy 83: 57-77.

Siti Khadijah A. Karim*

Fakulti Sains Gunaan

Universiti Teknologi MARA (UiTM) Jengka

26400 Bandar Tun Razak, Jengka, Pahang Darul Makmur Malaysia

Nik Marzuki Sidik

Fakulti Industri Asas Tani

Universiti Malaysia Kelantan Kampus Jeli

17600 Jeli, Kelantan Darul Naim

Malaysia

*Pengarang untuk surat-menyurat; email: khadijahkarim@ pahang.uitm.edu.my

Diserahkan: 16 Oktober 2017

Diterima: 26 April 2018 